\title{
Impact of Glucosinolate Content in Broccoli (Brassica oleracea (Italica Group)) on Growth of Pseudomonas marginalis, a Causal Agent of Bacterial Soft Rot
}

Craig S. Charron and Carl E. Sams, Department of Plant Sciences and Landscape Systems, The University of Tennessee, Knoxville 37901; and Craig H. Canaday, Department of Entomology and Plant Pathology, The University of Tennessee, West Tennessee Experiment Station, Jackson 38301

\begin{abstract}
Charron, C. S., Sams, C. E., and Canaday, C. H. 2002. Impact of glucosinolate content in broccoli (Brassica oleracea (Italica group)) on growth of Pseudomonas marginalis, a causal agent of bacterial soft rot. Plant Dis. 86:629-632.

Glucosinolate degradation products are known to suppress microbes. Brassica species produce glucosinolates. Previous investigations determined that susceptibility to bacterial soft rot of broccoli (Brassica oleracea (Italica group)) varied significantly by cultivar. To evaluate the impact of glucosinolates on Pseudomonas marginalis, a causal agent of bacterial soft rot, glucosinolates were measured in lyophilized florets from broccoli 'Arcadia', 'Emperor', 'Green Comet', 'Green Valiant', 'Marathon', 'Packman', 'Premium Crop', and 'Shogun'. Total glucosinolate content was highest in 'Shogun' $(29.8 \mu \mathrm{mol} / \mathrm{g})$ and lowest in 'Emperor' $(0.5 \mu \mathrm{mol} / \mathrm{g})$. In an in vitro assay, simple linear regression analysis showed that $48 \%$ of differences in suppression of $P$. marginalis growth could be explained by differences in total glucosinolate content $(P \leq 0.01)$. Plant breeding efforts should include glucosinolate levels as a factor in selecting for disease resistance.
\end{abstract}

Additional keywords: head rot, isothiocyanates

Bacterial soft rot of broccoli (Brassica oleracea L. (Italica group)) is a serious disease which can lead to $100 \%$ crop loss. This disease affects the inflorescence, and disease development is favored by prolonged periods of wet weather. Infected florets become water-soaked, necrotic, and malodorous (13). The etiology of soft rot is complex; Pseudomonas marginalis, other fluorescent Pseudomonas species, and Erwinia carotovora are commonly associated with the disease $(2,6,11)$. Primary infection appears to require bacteria that produce the biosurfactant viscosin and pectolytic enzymes (13). Viscosin enables the bacteria to wet the waxy surface of florets by promoting solute leakage (14). Pectolytic enzymes facilitate bacterial penetration of the epidermis. Pectolytic bacteria lacking the surfactant can only infect damaged tissue.

Susceptibility to bacterial soft rot varied significantly among cultivars in four field studies (7). 'Green Defender' and 'Shogun' had the lowest levels of disease incidence and severity. Horticultural traits such as head tightness, doming, floret size, and head weight/diameter ratio correlated sig-

Corresponding author: Carl E. Sams

E-mail: carlsams@utk.edu

Accepted for publication 30 January 2002.

Publication no. D-2002-0326-03R

(C) 2002 The American Phytopathological Society nificantly with genotypic resistance to bacterial soft rot (3). Brassica species produce glucosinolates, and glucosinolate degradation products suppress a wide variety of plant pathogens (21). Thus, they may also play a role in resistance to bacterial soft rot of broccoli.

Glucosinolates are secondary metabolites consisting of a thioglucose moiety, a sulfonated oxime, and a side group. Upon rupture of glucosinolate-containing cells, enzymatic hydrolysis of glucosinolates by endogenous myrosinase (thioglucoside glucohydrolase, EC 3.2.3.1) produces isothiocyanates, thiocyanates, nitriles, epithionitriles, and oxazolidine-2-thiones. Methyl and phenylethyl isothiocyanates from roots of B. juncea (L.) Czerniak and canola B. napus L. were inhibitory to Gaeumannomyces graminis (Sacc.) von Arx \& Olivier var. tritici Walker (1). Isothiocyanates inhibited conidia germination of the postharvest fruit pathogens Botrytis cinerea Pers.:Fr., Monilinia laxa (Aderhold \& Ruhland) Honey, Mucor piriformis E. Fisch., Penicillium expansum Link, and Rhizopus stolonifer (Ehrenb.:Fr.) Vuill. (18).

Reports of suppression of bacteria by isothiocyanates are primarily limited to human pathogens. Allyl isothiocyanate is used as a preservative in the food industry (8). Allyl and methyl isothiocyanates exhibited bactericidal activity against Escherichia coli $\mathrm{O} 157: \mathrm{H} 7$, Listeria monocytogenes, and Salmonella in sealed containers (17). Pseudomonas corrugata, a
Cytophaga species, and a fluorescent pseudomonad failed to grow when exposed to $500 \mu \mathrm{g}$ of allyl isothiocyanate per liter (9). Isshiki et al. (15) reported that 34 to $54 \mu \mathrm{g}$ of allyl isothiocyanate per liter prevented growth of the gram-negative bacteria $P$. aeruginosa IFO-13275, Vibrio parahaemolyticus IFO-12711, and E. coli JCM-1649; whereas 90 to $110 \mu \mathrm{g} / \mathrm{liter}$ were required to stop growth of gram positives such as $B a$ cillus cereus IFO-13494, B. subtilis IFO13722, Staphylococcus aureus IFO-12732, and $S$. enteritidis JCM-1891.

Since there is ample evidence for the antimicrobial properties of glucosinolate degradation products, our objectives were to measure glucosinolates in eight broccoli cultivars and determine whether glucosinolate content may be a factor in suppression of $P$. marginalis, a causal agent of bacterial soft rot.

\section{MATERIALS AND METHODS}

Cultivation of broccoli. Transplants of broccoli 'Arcadia', 'Emperor', 'Green Comet', 'Green Valiant', 'Marathon', 'Packman', 'Premium Crop', and 'Shogun' were produced in 128-cell Speedling trays in a greenhouse. Six-week-old seedlings were transplanted to plots at the Knoxville Experiment Station in late March 1995. Ammonium nitrate (34-0-0) was broadcast preplant at a rate of $67.25 \mathrm{~kg} \mathrm{~N} / \mathrm{ha}$, and sidedress applications of $67.25 \mathrm{~kg} \mathrm{~N} / \mathrm{ha}$ were added at 10 and 21 days after transplanting. A randomized block design with replication was used. Within each of four blocks, 20 plants of each cultivar were set $30.5 \mathrm{~cm}$ apart in a row. Three broccoli heads representing three replicates were selected for uniformity and harvested from each row at maturity from 23 May 1995 to 1 June 1995. Florets were diced, frozen at $-80^{\circ} \mathrm{C}$, lyophilized, and ground to a fine powder in a coffee mill.

Glucosinolate analysis. Ground, lyophilized florets (200 mg) were combined with $1 \mathrm{ml}$ of benzyl glucosinolate solution $(1 \mathrm{mM})$ as an internal standard, $2.0 \mathrm{ml}$ of methanol, and $0.3 \mathrm{ml}$ of barium-lead acetate $(0.6 \mathrm{M})$ in a $16 \times 100 \mathrm{~mm}$ culture tube and shaken at $60 \mathrm{rpm}$ for $1 \mathrm{~h}$. Each tube was then centrifuged at $2,000 \times g$ for 10 min. An aliquot of $0.5 \mathrm{ml}$ of supernatant was added to a $1-\mathrm{ml}$ column containing 0.3 $\mathrm{ml}$ of DEAE Sephadex A-25 and desulfated by the procedure of Raney and McGregor (20). 
Extracted desulfoglucosinolates were separated with a Hewlett-Packard (Palo Alto, CA) high-performance liquid chromatograph (HPLC) using a C-18 ODS reverse-phase column $(250 \times 4.6 \mathrm{~mm}$ I.D., $5-\mu \mathrm{m})$ and UV detector at a wavelength of $230 \mathrm{~nm}$. The column temperature was set at $35^{\circ} \mathrm{C}$. A flow rate of $1.5 \mathrm{ml} / \mathrm{min}$ was used. For $1 \mathrm{~min}$, the solvent was $100 \%$ water. After a 15-min linear gradient to $75 \%$ water and $25 \%$ acetonitrile, the solvent levels were constant for $5 \mathrm{~min}$, and over the final $5 \mathrm{~min}$ a linear gradient to $100 \%$ water was used. Desulfoglucosinolates were identified by comparison with retention times of authentic standards or previously reported results (12).

Preparation of inoculum for bioassay. A soft-rotting $P$. marginalis culture was obtained from Bonnie Ownley of the Entomology and Plant Pathology Department at the University of Tennessee. Virulence was confirmed with tests on fresh broccoli florets purchased from a local market. All lab ware and instruments were sterilized before use by autoclave or with a 5\% $\mathrm{NaOCl}$ solution. Water and nutrient broth were sterilized by autoclave. A bacterial loop was used to transfer some of the plated $P$. marginalis to $50 \mathrm{ml}$ of Difco nutrient broth (Becton Dickinson, Sparks, $\mathrm{MD})$ in a 250-ml Erlenmeyer flask. The mouth of the flask was loosely plugged with cotton and incubated overnight at $23^{\circ} \mathrm{C}$ at $150 \mathrm{rpm}$. Immediately before conducting the assay, the absorbance of the inoculated solution was measured with a Shimadzu UV 260 (Columbia, MD) spectrophotometer operating at $400 \mathrm{~nm}$. Based on a standard curve relating absorbance to colony-forming units (CFUs), $5 \mathrm{ml}$ of the inoculated solution was diluted to $10^{5}$ $\mathrm{CFU} / \mathrm{ml}$ in nutrient broth.

Preparation of broccoli for bioassay. Three replicates of each cultivar of lyophilized broccoli florets from each of the four blocks were used, and $600 \pm 1 \mathrm{mg}$ of each sample was placed in a $16 \times 100 \mathrm{~mm}$ culture tube. An $8.0-\mathrm{ml}$ aliquot of water $\left(100^{\circ} \mathrm{C}\right)$ was added, and the tube was placed in a water bath at $100^{\circ} \mathrm{C}$. After $3 \mathrm{~min}$, the sample was removed and vortexed for $15 \mathrm{~s}$, then centrifuged at $4,000 \times g$ for $15 \mathrm{~min}$ at $15^{\circ} \mathrm{C}$. The supernatant was transferred to an $8.0-\mathrm{ml}$ plastic cup. The pellet was re-extracted with $2.0 \mathrm{ml}$ of water $\left(100^{\circ} \mathrm{C}\right)$, vortexed, and centrifuged, and the supernatant was combined with that from the first extraction. Prestera et al. (19) used a similar method for extraction of glucosinolates from broccoli. A myrosinase solution was prepared by adding sufficient water to $5.75 \mathrm{mg}$ of myrosinase (487 units per g; Sigma-Aldrich Co., St. Louis, $\mathrm{MO})$ to achieve a volume of $10 \mathrm{ml}$ and sterilized with a 0.8/0.2- $\mu \mathrm{m}$ syringe filter (Pall Corp., Ann Arbor, MI).

Bioassay protocol. For each sample, 4.5 $\mathrm{ml}$ of broccoli extract was filter-sterilized. A reference cuvette ( $\mathrm{cuv}^{\text {ref }}$ ) was prepared by combining $1.5 \mathrm{ml}$ of broccoli extract with $25 \mu \mathrm{l}$ of nutrient broth and $200 \mu \mathrm{l}$ of water, transferring the mixture to a $1.5-\mathrm{ml}$ cuvette, and covering with surfacesterilized Parafilm. A cuvette containing broccoli extract and $P$. marginalis $\left(\mathrm{cuv}^{-\mathrm{myr}}\right.$ ) was prepared by combining $1.5 \mathrm{ml}$ of extract, $25 \mu \mathrm{l}$ of inoculating solution, and 200 $\mu \mathrm{l}$ of water. A third cuvette contained 1.5 $\mathrm{ml}$ of extract, $25 \mu \mathrm{l}$ of inoculating solution, and $200 \mu \mathrm{l}$ of myrosinase solution $\left(\mathrm{cuv}^{+\mathrm{myr}}\right)$. P. marginalis growth was determined at $0,24,48,72$, and 84 h by measuring the absorbance $(400 \mathrm{~nm})$ of the cuvette containing myrosinase and that of the cuvette without myrosinase in comparison to the reference cuvette.
To determine the effects of myrosinase on $P$. marginalis growth in a nonglucosinolate-containing medium, $1.5 \mathrm{ml}$ of nutrient broth was combined with $25 \mu$ l of nutrient broth and $200 \mu \mathrm{l}$ of water, and transferred to a reference cuvette. A second cuvette contained $1.5 \mathrm{ml}$ of nutrient broth, $25 \mu$ of inoculating solution, and $200 \mu \mathrm{l}$ of water. An aliquot of $200 \mu \mathrm{l}$ of myrosinase solution was added to $1.5 \mathrm{ml}$ of nutrient broth and $25 \mu \mathrm{l}$ of inoculating solution and added to a third cuvette. Absorbances were measured according to the procedure used for the inoculated broccoli extracts.

To determine if available sugars affected bacterial growth in the broccoli extracts, subsamples were removed from all cuvettes in the second block, which contained three replicates of each cultivar, filtered through a $0.2-\mu \mathrm{m}$ filter, and soluble solids levels (degrees Brix) were measured by refractometer.

Fisher's protected least significant difference (LSD) test was used for separation of means of total and individual glucosinolate levels, and Brix values (SAS Institute, Cary, NC). The relationship between glucosinolate content and suppression of $P$. marginalis was examined by simple linear regression analysis.

\section{RESULTS}

Glucosinolate content in broccoli florets. The eight cultivars were separated

Table 2. Soluble solids levels of cultivars and number of cuvette pairs with bacterial growth in both the cuvette with myrosinase $\left(\mathrm{cuv}^{+\mathrm{myr}}\right)$ and the cuvette without myrosinase $\left(\mathrm{cuv}^{-\mathrm{myr}}\right)^{\mathrm{z}}$

\begin{tabular}{lcccc}
\hline & $\begin{array}{c}\text { Pairs of cuvettes with } \\
\text { bultivar }\end{array}$ & Reference & Cuv $^{+ \text {myr }}$ & Cuv $^{\text {-myr }}$ \\
\hline Shogun & 7 & $3.00 \mathrm{a}$ & $3.03 \mathrm{a}$ & $2.43 \mathrm{a}$ \\
Green Comet & 7 & $2.75 \mathrm{ab}$ & $2.23 \mathrm{c}$ & $1.93 \mathrm{~b}$ \\
Marathon & 7 & $2.70 \mathrm{~b}$ & $2.85 \mathrm{ab}$ & $2.15 \mathrm{ab}$ \\
Packman & 1 & $2.57 \mathrm{bc}$ & $2.58 \mathrm{bc}$ & $2.53 \mathrm{a}$ \\
Premium Crop & 0 & $2.53 \mathrm{bc}$ & $2.55 \mathrm{bc}$ & $2.43 \mathrm{a}$ \\
Emperor & 0 & $2.50 \mathrm{bc}$ & $2.48 \mathrm{c}$ & $2.53 \mathrm{a}$ \\
Arcadia & 4 & $2.40 \mathrm{c}$ & $2.55 \mathrm{bc}$ & $1.90 \mathrm{~b}$ \\
Green Valiant & 3 & $2.33 \mathrm{c}$ & $2.45 \mathrm{c}$ & $1.70 \mathrm{~b}$ \\
\hline
\end{tabular}

${ }^{z}$ Mean separation within columns by Fisher's protected least significant difference $(P \leq 0.05)$.

Table 1. Glucosinolates detected in florets from eight cultivars of broccoli (Brassica oleracea (Italica group)), listed in order from highest to lowest total glucosinolates ${ }^{\mathrm{x}, \mathrm{y}}$

\begin{tabular}{|c|c|c|c|c|c|c|c|c|c|c|c|}
\hline \multirow[b]{2}{*}{ Cultivar } & \multicolumn{11}{|c|}{ Glucosinolate concentration $(\mu \mathrm{mol} / \mathrm{g})$} \\
\hline & $\begin{array}{c}\text { 3-Methyl- } \\
\text { sulfinyl- } \\
\text { propyl }\end{array}$ & $\begin{array}{c}\text { (2R)-2- } \\
\text { Hydroxy- } \\
\text { but-3-enyl }\end{array}$ & $\begin{array}{c}\text { 4-Methyl- } \\
\text { sulfinyl- } \\
\text { butyl }\end{array}$ & $\begin{array}{c}\text { But-3- } \\
\text { enyl }\end{array}$ & $\begin{array}{l}\text { Indol-3- } \\
\text { ylmethyl }\end{array}$ & $\begin{array}{l}\text { 4-Methoxy- } \\
\text { indol-3- } \\
\text { ylmethyl }\end{array}$ & $\begin{array}{c}\text { N-Methoxy- } \\
\text { indol-3- } \\
\text { ylmethyl }\end{array}$ & $\begin{array}{l}\text { Aliphatic } \\
\text { glucosi- } \\
\text { nolates }\end{array}$ & $\begin{array}{l}\text { Indole } \\
\text { glucosi- } \\
\text { nolates }\end{array}$ & Total & $\begin{array}{c}\text { Disease } \\
\text { incidence } \\
(\%)^{\mathrm{z}}\end{array}$ \\
\hline Shogun & $0.86 \mathrm{bc}$ & $1.80 \mathrm{~b}$ & $15.35 \mathrm{a}$ & $0.31 \mathrm{a}$ & $4.17 \mathrm{~b}$ & $0.24 \mathrm{a}$ & $6.76 \mathrm{a}$ & $18.64 \mathrm{a}$ & $11.17 \mathrm{a}$ & $29.82 \mathrm{a}$ & $6.0 \mathrm{a}$ \\
\hline Arcadia & $1.00 \mathrm{ab}$ & $1.76 \mathrm{~b}$ & $13.21 \mathrm{~b}$ & $0.34 \mathrm{a}$ & $3.10 \mathrm{c}$ & $0.21 \mathrm{a}$ & $4.55 \mathrm{~b}$ & $16.55 \mathrm{a}$ & $7.86 \mathrm{~b}$ & $24.42 \mathrm{~b}$ & $9.2 \mathrm{ab}$ \\
\hline Marathon & $1.02 \mathrm{a}$ & $0.00 \mathrm{e}$ & $10.02 \mathrm{c}$ & $0.08 \mathrm{bc}$ & $5.49 \mathrm{a}$ & $0.24 \mathrm{a}$ & $6.02 \mathrm{a}$ & $11.24 \mathrm{~b}$ & $11.75 \mathrm{a}$ & $22.98 \mathrm{~b}$ & $4.5 \mathrm{a}$ \\
\hline Green Valiant & $0.76 \mathrm{c}$ & $1.19 \mathrm{c}$ & $9.21 \mathrm{c}$ & $0.13 \mathrm{~b}$ & $3.71 \mathrm{bc}$ & $0.10 \mathrm{~b}$ & $1.30 \mathrm{c}$ & $11.53 \mathrm{~b}$ & $5.11 \mathrm{c}$ & $16.64 \mathrm{c}$ & $34.5 \mathrm{c}-\mathrm{e}$ \\
\hline Premium Crop & $0.00 \mathrm{~d}$ & $2.14 \mathrm{a}$ & $9.24 \mathrm{c}$ & $0.35 \mathrm{a}$ & $3.38 \mathrm{bc}$ & $0.08 \mathrm{~b}$ & $1.22 \mathrm{~cd}$ & $11.84 \mathrm{~b}$ & $4.68 \mathrm{c}$ & $16.52 \mathrm{c}$ & $64.1 \mathrm{~g}$ \\
\hline Green Comet & $0.00 \mathrm{~d}$ & $0.82 \mathrm{~d}$ & $5.18 \mathrm{~d}$ & $0.09 \mathrm{~b}$ & $0.57 \mathrm{~d}$ & $0.04 \mathrm{c}$ & $0.09 \mathrm{de}$ & $6.15 \mathrm{c}$ & $0.69 \mathrm{~d}$ & $6.84 \mathrm{~d}$ & $58.1 \mathrm{fg}$ \\
\hline Packman & $0.00 \mathrm{~d}$ & $0.05 \mathrm{e}$ & $0.49 \mathrm{e}$ & $0.00 \mathrm{c}$ & $0.23 \mathrm{~d}$ & $0.01 \mathrm{c}$ & $0.02 \mathrm{e}$ & $0.89 \mathrm{~d}$ & $0.26 \mathrm{~d}$ & $1.16 \mathrm{e}$ & $46.2 \mathrm{~d}-\mathrm{g}$ \\
\hline Emperor & $0.00 \mathrm{~d}$ & $0.00 \mathrm{e}$ & $0.41 \mathrm{e}$ & $0.00 \mathrm{c}$ & $0.10 \mathrm{~d}$ & $0.00 \mathrm{c}$ & $0.01 \mathrm{e}$ & $0.41 \mathrm{~d}$ & $0.11 \mathrm{~d}$ & $0.53 \mathrm{e}$ & $34.0 \mathrm{c}-\mathrm{e}$ \\
\hline
\end{tabular}

x Mean separation within columns by Fisher's protected least significant difference $(P \leq 0.05)$.

y Glucosinolate means determined from four blocks and three replicates per block.

${ }^{\mathrm{z}}$ Disease incidence reported by Canaday (5). 
into five groups based on mean separation of total glucosinolates (Table 1). 'Shogun' had the highest level of total glucosinolates $(29.8 \mu \mathrm{mol} / \mathrm{g})$ and 4-methylsulfinylbutyl $(15.35 \mu \mathrm{mol} / \mathrm{g})$, which was the predominant glucosinolate for all cultivars. 'Arcadia' (24.42 $\mu \mathrm{mol} / \mathrm{g}$ ) and 'Marathon' (22.98 $\mu \mathrm{mol} / \mathrm{g})$ had the second highest level of total glucosinolates. The group with the third highest level of glucosinolates consisted of 'Green Valiant' $(16.64 \mu \mathrm{mol} / \mathrm{g})$ and 'Premium Crop' $(16.52 \mu \mathrm{mol} / \mathrm{g})$. 'Green Comet' (6.84 $\mu \mathrm{mol} / \mathrm{g}$ ) was the fourth highest in total glucosinolates, and 'Emperor' (0.53 $\mu \mathrm{mol} / \mathrm{g})$ and 'Packman' (1.16 $\mu \mathrm{mol} / \mathrm{g})$ were lowest of all cultivars. Indole glucosinolates, as a percent of the total, ranged from $10.1 \%$ for 'Green Comet' to $51.1 \%$ for 'Marathon'.

P. marginalis bioassay. Of 192 (two cuvettes $\times$ eight cultivars $\times$ four blocks $\times$ three replicates) cuvettes containing inoculated broccoli florets extract, 79 cuvettes evidenced bacterial growth by increased absorbance and growth when transferred to nutrient agar. There were 29 samples in which bacteria grew in both cuv $^{\text {+myr }}$ and cuv'-myr.

'Shogun', 'Green Comet', and 'Marathon' initially had the highest soluble solids levels (based on reference cuvettes) and the most pairs of cuvettes with bacterial growth (Table 2). 'Arcadia' and 'Green Valiant' had the lowest soluble solids levels. There were no pairs of cuvettes with bacterial growth with extracts from 'Premium Crop' or 'Emperor'.

Analyses of relative bacterial growth in cuv $^{+m y r}$ and cuv $^{-m y r}$ were conducted when growth occurred in both cuvettes. The difference in mean absorbance (absorbance of extract in cuv ${ }^{-m y r}-$ absorbance of extract in $\mathrm{cuv}^{+\mathrm{myr}}$ ) was negative for 'Arcadia', 'Marathon', and 'Shogun' at $24 \mathrm{~h}$, indicating that bacterial growth initially was more rapid in extracts containing myrosinase (Fig. 1). These cultivars also contained higher total glucosinolate levels than the other cultivars.

'Arcadia', 'Green Comet', 'Green Valiant', 'Marathon', and 'Shogun' all had at least three pairs of cuvettes (cuv ${ }^{-m y r}$ and cuv $^{+m y r}$ ) in which bacterial growth was observed (Table 2). When total glucosinolate data of these cultivars were pooled together and suppression of $P$. marginalis at $84 \mathrm{~h}$ was expressed in percent as $100 *$ (absorbance of cuv $^{-\mathrm{myr}}$ - absorbance of cuv $\left.^{+m y r}\right) /\left(\right.$ absorbance of cuv $\left.{ }^{-m y r}\right)$, simple linear regression indicated that total glucosinolates explained $48 \%$ of differences in level of suppression ( $P \leq 0.01$; Fig. 2$)$. Fifty-one percent of differences in suppression could be explained by differences in 3-methylsulphinyl propyl glucosinolate $(P$ $\leq 0.01)$. Less than $48 \%$ of suppression differences could be explained by the group of aliphatic or indole glucosinolates $(P \leq 0.01)$ or by individual glucosinolates
( $P \leq 0.05$ for 3 -butenyl glucosinolate, $P \leq$ 0.01 for all others; data not shown).

\section{DISCUSSION}

Variation in glucosinolate content among cultivars has been reported previously $(10,23,24)$. Kushad et al. (16) measured glucosinolates in the entire edible portion of 'Shogun', 'Premium Crop', 'Green Comet', and 'Packman', and reported total glucosinolate levels of 25.8, $10.7,10.4$, and $8.0 \mu \mathrm{mol} / \mathrm{g}$, respectively. Although the order from highest to lowest glucosinolate levels was the same as we measured, we found a wider range between total glucosinolates of 'Premium Crop' and 'Packman'. This dissimilarity with the results of Kushad et al. may have occurred because we measured glucosinolates in the florets, whereas Kushad et al. used the entire edible portion. An uneven distribution of glucosinolates within the broccoli head could account for the difference.

Comparison of glucosinolate levels from this study with bacterial soft rot resistance for cultivars reported by Canaday (5) re-

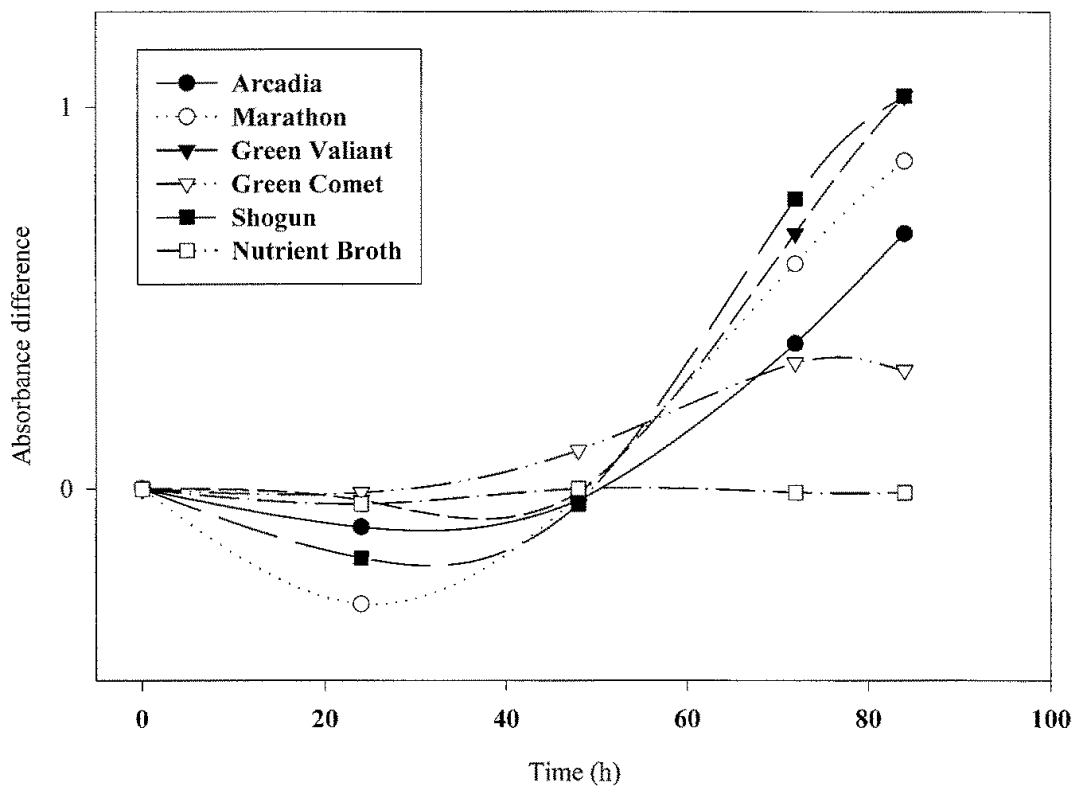

Fig. 1. Absorbance difference of cultivars calculated as mean absorbance of broccoli florets extract without myrosinase minus mean absorbance of broccoli florets extract containing myrosinase. Nutrient broth was used as a control for comparison.

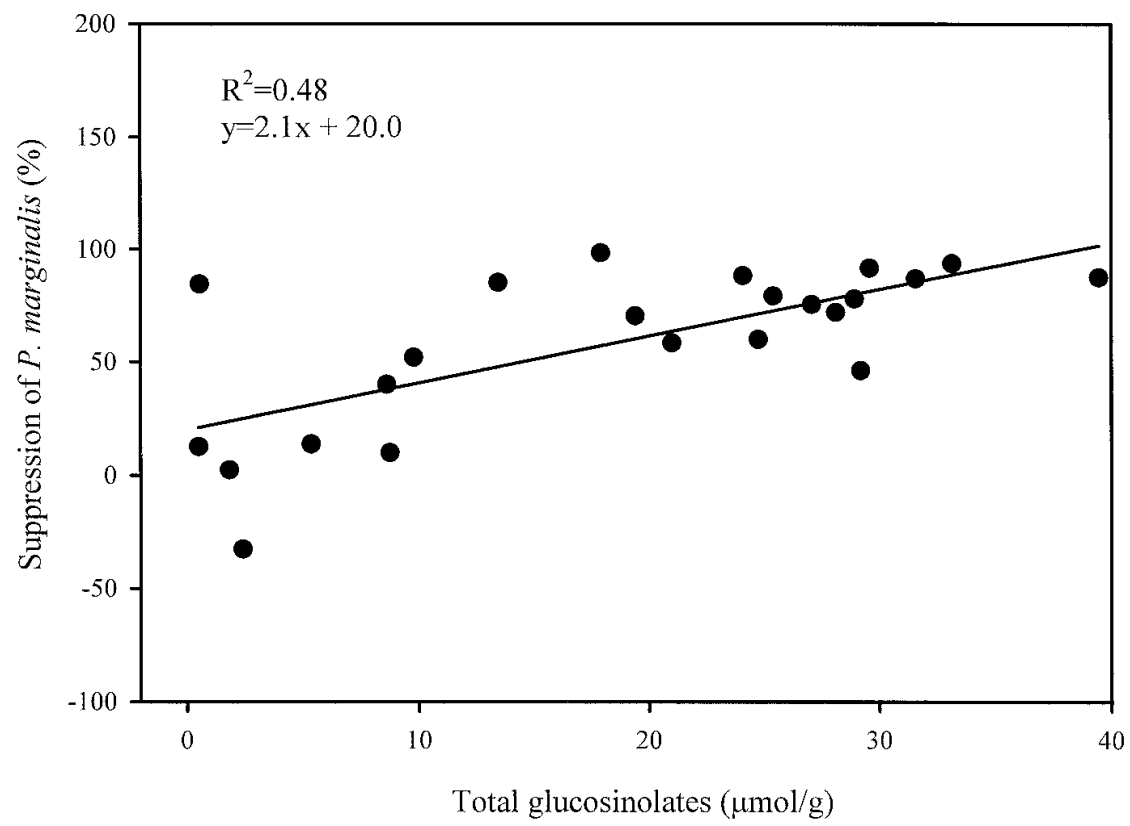

Fig. 2. Suppression of Pseudomonas marginalis in cuvettes with myrosinase (cuv ${ }^{+m y r}$ ) relative to cuvettes without myrosinase (cuv-myr), calculated as absorbance of (cuv $v^{-m y r}-$ cuv $\left.^{\text {-myr }}\right) * 100 /$ cuv $^{-m y r}$. Suppression is plotted against total glucosinolate levels in broccoli florets. 
veals that cultivars with high levels of glucosinolates tend to be resistant to bacterial soft rot (Table 1). 'Shogun', 'Arcadia', and 'Marathon' had the highest total glucosinolate content and the lowest disease incidence in the field. For the five cultivars with total glucosinolate content below $22.95 \mu \mathrm{g} / \mathrm{g}$, soft rot was severe. Comparison of the laboratory response with field observation indicates that cultivars with glucosinolate content greater than or equal to $22.95 \mu \mathrm{g} / \mathrm{g}$ may suppress soft rot incidence.

'Green Valiant' and 'Emperor' had similar disease incidence but had significantly different total glucosinolate levels. 'Green Valiant' and 'Premium Crop' had significantly different disease incidence but similar total glucosinolate levels. These results are evidence that other factors may interact with total glucosinolate level in affecting resistance to bacterial soft rot. In a previous study, Canaday (3) determined that head weight/diameter ratio, head tightness, doming, and floret size correlate significantly with soft rot incidence and severity. These horticultural traits may interact with total glucosinolate level in affecting overall disease resistance.

Although 'Shogun', 'Green Comet', and 'Marathon' initially had the highest soluble solids levels (based on reference cuvettes) and the most pairs of cuvettes with bacterial growth, 'Arcadia' and 'Green Valiant' had the lowest soluble solids levels but did not have the least number of pairs of cuvettes with bacterial growth. Thus, sugar levels were not a primary factor in determining whether $P$. marginalis would proliferate in broccoli extracts. The $\mathrm{pH}$ of extracts was not adjusted to the same level, and this may explain differences in suitability for bacterial growth. Moreover, other compounds besides glucosinolate degradation products may have affected bacterial growth. Plant tissue frequently has a wide array of antimicrobial compounds (25). Since horticultural traits cannot explain differences in $P$. marginalis growth in broccoli extract, it seems likely that chemical compounds in addition to glucosinolates affected bacterial growth.

The antimicrobial activity associated with glucosinolates is usually attributed to their breakdown products, primarily isothiocyanates (22). Therefore, the addition of myrosinase to broccoli extract should result in the generation of glucosinolate degradation products, which if toxic to $P$. marginalis would affect subsequent growth compared with samples lacking myrosinase. It is possible that glucose liberated by glucosinolate hydrolysis in cuv $^{\text {myr }}$ initially was more favorable to $P$. marginalis growth than were degradation products such as isothiocyanates detrimental to growth. After $24 \mathrm{~h}$, mean absorbance difference increased for all cultivars, indicating that bacterial growth increased more rapidly in extracts lacking myrosinase. The mean absorbance difference of nutrient broth did not appear to change over time, demonstrating that myrosinase in and of itself did not affect $P$. marginalis growth.

The clear differences in glucosinolate levels among the cultivars tested are a basis for determining the importance of glucosinolates in broccoli susceptibility to bacterial soft rot. Glucosinolates seem to be one of many factors affecting disease incidence and severity, and there may be interactions among these factors. The data reported here indicate that plant breeders should consider glucosinolate levels as an important factor to measure in developing broccoli lines resistant to bacterial soft rot.

\section{LITERATURE CITED}

1. Angus, J. F., Gardner, P. A., Kirkegaard, J. A., and Desmarchelier, J. M. 1994. Biofumigation: Isothiocyanates released from Brassica roots inhibit growth of the take-all fungus. Plant Soil 162:107-112.

2. Brokenshire, T., and Robertson, N. H. 1986. Control of callabrese spear rot with copper fungicides. Tests of Agrochemical and Cultivars No. 7. Ann. Appl. Biol. 108:52-53.

3. Canaday, C. H. 1989. Identification of horticultural traits for predicting broccoli cultivar susceptibility to bacterial soft rot. (Abstr.) Phytopathology 79:1160.

4. Canaday, C. H. 1993. Reactions of new broccoli cultivars and one experimental line to bacterial soft rot. Biol. Cult. Tests 8:16.

5. Canaday, C. H. 1995. Reactions of new broccoli cultivars and five experimental lines to bacterial soft rot, 1994. Biol. Cult. Tests 10:128.

6. Canaday, C. H., Mullins, C. A., Wyatt, J. E., Coffey, D. L., Mullins, J. A., and Hall, T. 1987. Bacterial soft rot of broccoli in Tennessee. (Abstr.) Phytopathology 77:1712.

7. Canaday, C. H., Wyatt, J. E., and Mullins, J. A. 1991. Resistance in broccoli to bacterial soft rot caused by Pseudomonas marginalis and fluorescent Pseudomonas species. Plant Dis. 75:715-720.

8. Delaquis, P. J., and Mazza, G. 1995. Antimicrobial properties of isothiocyanates in food preservation. Food Technol. 49:73-84.

9. Delaquis, P. J., and Sholberg, P. L. 1997. Antimicrobial activity of gaseous allyl isothiocyanate. J. Food. Prot. 60:943-947.

10. Goodrich, R. M., Anderson, J. L., and Stoewsand, G. S. 1989. Glucosinolate changes in blanched broccoli and brussels sprouts. J. Food Proc. Preserv. 13:275-280.

11. Hansen, J. D. 1985. Common names for plant diseases. Plant Dis. 69:649-676.

12. Hansen, M., Møller, P., Sørensen, H., and Cantwell de Trejo, M. 1995. Glucosinolates in broccoli stored under controlled atmosphere. J. Am. Soc. Hortic. Sci. 120:1069-1074.

13. Hildebrand, P. D. 1989. Surfactant-like characteristics and identity of bacteria associated with broccoli head rot in Atlantic Canada. Can. J. Plant Pathol. 11:205-214.

14. Hildebrand, P. D., Laycock, M. V., and Thibault, P. 1990. Biosurfactant production by pectolytic fluorescent pseudomonads and its role in broccoli head rot. Can. J. Plant Pathol. 12:334.

15. Isshiki, K., Tokuora, K., Mori, R., and Chiba, S. 1992. Preliminary examination of allyl isothiocyanate vapor for food preservation. Biosci. Biotech. Biochem. 56:1476-1477.

16. Kushad, M. M., Brown, A. F., Kurilich, A. C., Juvik, J. A., Klein, B. P., Wallig, M. A., and Jeffery, E. H. 1999. Variation of glucosinolates in vegetable crops of Brassica oleracea. J. Agric. Food Chem. 47:1541-1548.

17. Lin, C., Kim, J., Du, W., and Wei, C. 2000 Bactericidal activity of isothiocyanate against pathogens on fresh produce. J. Food Prot. 63:25-30.

18. Mari, M., Iori, R., Leoni, O., and Marchi, A. 1993. In vitro activity of glucosinolatederived isothiocyanates against postharvest fruit pathogens. Appl. Biol. 123:155-164.

19. Prestera, T., Fahey, J. W., Holtzclaw, W. D., Abeygunawardana, C., Kachinski, J. L., and Talalay, P. 1996. Comprehensive chromatographic and spectroscopic methods for the separation and identification of intact glucosinolates. Anal. Biochem. 239:168-179.

20. Raney, J. P., and McGregor, D. I. 1990. Determination of glucosinolate content by gas liquid chromatography of trimethylsilyl derivatives of desulfated glucosinolates. Proc. Oil Crops Network, Shanghai, China, 21-23 Apr.

21. Rosa, E. A. S., Heaney, R. K., Fenwick, G. R., and Portas, C. A. M. 1997. Glucosinolates in crop plants. Pages 99-215 in: Horticultural Reviews. J. Janick, ed. John Wiley \& Sons, New York.

22. Sarwar, M., Kirkegaard, J. A., Wong, P. T. W. and Desmarchelier, J. M. 1998. Biofumigation potential of brassicas. III. In vitro toxicity of isothiocyanates to soil-borne fungal pathogens. Plant Soil 201:103-112.

23. Shelp, B. J., Liu, L., and McLellan, D. 1993. Glucosinolate composition of broccoli (Bras sica oleracea var. italica) grown under various boron treatments at three Ontario sites. Can. J. Plant Sci. 73:885-888.

24. Shelp, B. J., Shattuck, V. I., McLellan, D., and Liu, L. 1992. Boron nutrition and the composition of glucosinolates and soluble nitrogen compounds in two broccoli (Brassica oleracea var. italica) cultivars. Can. J. Plant Sci. 72:889-899.

25. Urbasch, I. 1984. Production of $\mathrm{C}^{6}$-wound gases by plants and the effect on some phytopathogenic fungi. Z. Naturforsch. 39c:10031007. 